\title{
Az üzleti kapcsolatok erkölcsi újjáépítése - Menedzsment szemlélet keresztény nézőpontból
}

\author{
TÓTH ESZTER ${ }^{1}$ - DR. CSAPÓNÉ DR. RISKÓ TÜNDE²
}

\begin{abstract}
ABSZTRAKT
A globalizáció történelmi időkön átívelő, igen összetett folyamat. A nagy földrajzi felfedezésekhez köthető a kezdete, a világkereskedelem és a világpiac kialakulásával folytatódott és jutott el jelenkori állapotáig. A globalizációnak pozitív és negatív hozadékai egyaránt vannak. A pozitív hozadékok között ki kell emelnünk, hogy a világ egyre nagyobb területein élvezik a tudomány és a technika vívmányait, egyre több ember jut tanulási lehetőséghez, alapvető szükségleteket kielégítő javakhoz. A vállalkozások hatékonyságát növeli, új lehetőségeket kínál, hiszen gyakorlatilag határok nélküli hozzáférést biztosít nyersanyagokhoz, munkaeröhöz és tudáshoz. A negatív hatások között meg kell említeni a bioszféra pusztulását, a gazdasági és társadalmi egyenlőtlenségek fokozódását, különösképpen a fejlődő országokban. Számos vállalat az egész világra kiterjesztette múködését és olyan hatalmas gazdasági erővel, befolyással rendelkezik, hogy felettük korlátozott a kormányok szabályozó képessége. A profitért folytatott küzdelemnek magas ára van, amit a vállalatok gyakran a társadalmi-természeti környezetre hárítanak. Tanulmányunk célja áttekinteni, hogyan lehetne ember-, illetve környezetbarátabbá tenni napjaink üzleti kapcsolatait - a keresztény filozófia szellemében. Meg kell jegyezni, hogy habár tanulmányunk a keresztény alapú nézőpontra fókuszál, természetesen globalizált világunk üzleti kapcsolatainak vizsgálatakor nem szabad kihagyni az egyéb világvallások meghatározó szerepét sem.
\end{abstract}

KULCSSZAVAK: globalizáció, gazdaság, menedzsment, erkölcs, vallás, közjó

\section{ABSTRACT}

\section{The moral restoration of business relations - Management from a Christian point of view}

Globalisation is a complex and worldwide process overarching historical times and continents. It started with the great geographical discoveries, continued with the emergence of world trade and the development of a truly global market reaching its present status. Globalisation has both negative and positive effects. Out of the positive effects it has to be emphasised that more and more zones of our planet benefit from the advances in sciences and techniques, more and more

${ }^{1}$ Ügyvivő szakértő, Debreceni Egyetem Gazdaságtudományi Kar, Világgazdasági és Nemzetközi Kapcsolatok Intézet, Világgazdasági és Nemzetközi Üzleti Tanszék.

${ }^{2}$ Adjunktus, Debreceni Egyetem Gazdaságtudományi Kar, Marketing és Kereskedelem Intézet. 


\title{
TEMATIKUS TANULMÁNYOK - Menedzsment: vezetők, vezetés és munkavállalók
}

people have better access to work, education and the necessary commodities to meet their basic needs. Globalisation has brought efficiency and new opportunities to companies, providing practically free access to raw materials, labour and knowledge. Out of the negative effects degradation of the biosphere, the greater social and economic inequality especially in the developing countries has to be pointed out. Some companies are operating worldwide and have acquired great economic power and influence. Governments have only limited possibilities to regulate their operation. The expenses of profit maximisation are high, which are often 'paid' by the social-natural environment (as externalities). The aim of our study is to overview how current business relations could be formed to be more human and environment friendly from the point of view of Christian philosophy. It has to be pointed out that our study is focusing on the Christian point of view, although in our globalised world when studying business relations we should not forget about the role of other world major religious groups.

KEYWORDS: globalisation, economy, management, moral, religion, common good

\begin{abstract}
„Régóta eltorzultak a legalapvetőbb gazdasági kapcsolatok, és kihaltak a gazdasági élethez tartozó erények, mint az igazmondás, a megbízhatóság és a szorgalom. Türelmes anyagi és erkölcsi újjáépítésre van tehát szükség, miközben a hosszú nélkülözésben kimerült népek kormányaiktól életszínvonaluk érezhetö, gyors emelkedését, valamint jogos igényeiknek megfelelő kielégítését várják (II. János Pál pápa CENTESIMUS ANNUS 1991/27)."
\end{abstract}

\section{Bevezetés}

Korunk gazdasági-társadalmi történéseihez, a globalizációhoz, a modern kommunikációs technológiáknak köszönhető információátviteli sebességhez pozitív és negatív hatások egyaránt társulnak. Harrington et al. (2014: 8) így fogalmaz: „A 'globalizáció' kifejezés elsősorban a munkára és a tőkére vonatkozó input és output egész földet behálózó mozgására, valamint a társadalmi kapcsolatok növekvő hálójára utal." A vállalatok gyakorlatilag határok nélkül tudnak hozzájutni a müködésükhöz szükséges alapanyagokhoz, nyersanyagokhoz a legjobb minőségben és a legjobb áron. A tevékenységeikhez nélkülözhetetlen tudáshoz és emberi erőforrásokhoz úgyszintén a világ bármely pontján kvázi szabad hozzáférésük van a legjobb, legkedvezőbb lehetőségeket keresve. A hidegháború befejezésével és a fejlődő piacok megnyílásával az üzleti élet világszinten jelentősen felpezsdült, ami előnyöket, lehetőségeket, de veszélyeket is hozott magával. Akik korábban el/ki voltak zárva a világgazdaság rendszeréből, ma már szereplői, haszonélvezői, formálói lehetnek. A világ egyre nagyobb részén jutnak az emberek alapvető szükségleteiket kielégítő javakhoz, ivóvízhez, orvosi ellátáshoz, tanulási és munkalehetőséghez, tudnak részesülni a tudomány és technika vívmányaiból. A vállalatok hatékonysága megnőtt, egyre több termék és szolgáltatás jelenik meg a piacon és válik egyre nagyobb tömegek számára hozzáférhetővé. Mint negatív hozadék meg kell említenünk, hogy 


\section{TEMATIKUS TANULMÁNYOK - Menedzsment: vezetők, vezetés és munkavállalók}

nemcsak a világ termelési szintje emelkedett meg, hanem a vagyon és a jövedelem eloszlásának egyenlőtlensége is, mind az egyes országokon belül, mind pedig a különböző országok között. Szintén kedvezőtlen tendencia a kulturális homogenitás fokozódása, továbbá leginkább a nyugati kultúrákban az individualizmus előtérbe kerülése, a haszonelvü-énközpontúság terjedése és a családi kapcsolatok egyre gyakoribb felbomlása (Harrington et al. 2014). „Dicsérnünk kell azokat a sikereket, melyek hozzájárulnak az egyén jólétéhez, például az egészségügy, a nevelés és a kommunikáció területén" írja Ferenc pápa (Tornielli - Galeazzi 2015: 58). Elismeri, hogy a globalizáció sok embernek segített kiemelkedni a szegénységből, sokakat azonban éhhalálra ítélt. Elfogadja, hogy összértékben nőtt a világ gazdagsága, de rávilágít, hogy nőttek az egyenlőtlenségek is és újfajta szegénység jelent meg a bolygón. Igen sokan nap, mint nap bizonytalanságban élnek, terjednek egyes betegségek, nő a félelem és a reménytelenség még a gazdagabb országokban is, halványul az életöröm, gyakori a tisztelet hiánya és az erőszak, és egyre nyilvánvalóbb az egyenlőtlenség (Ferenc pápa 2013). Naponta 24.000 ember hal éhen a nagyvilágban. 25 millióval nő évente az ínséget szenvedők száma. Világszinten 300 millió gyermek nem kap a szervezete fejlődéséhez szükséges táplálékot. 11 millió kisgyermek hal meg éhség vagy alultápláltság következtében évente. A hagyományosan polgárháború sújtotta övezetekben (pl. Szudán) a gyermekek 60 százaléka nem jut minden nap élelemhez (Kriston 2010). Programadó szövegében azt is említi Ferenc pápa, hogy miközben kevesek jövedelme hatványozottan emelkedik, a többség egyre távolabb kerül ezen szerencsés kisebbség jólététől (Ferenc pápa 2013). Ez a különbség olyan ideológiákból ered, amelyek védelmezik a piacok teljes körű autonómiáját és a pénzügyi spekulációt. Ferenc pápa felhívja a figyelmet a politika igen fontos feladatára, miszerint annak a közjót és az embereket kell szolgálnia. Úgy fogalmaz, hogy az emberi jogokat nemcsak az elnyomás, a terrorizmus, vagy a gyilkosságok sértik, hanem a szélsőséges szegénység élethelyzeteinek és az igazságtalan gazdasági struktúráknak a fennállása is, amelyek óriási egyenlőtlenségeket okoznak. A globalizáció nem gátolhatja meg az országokat, a nemzetközi szervezeteket abban, hogy minden lehetőt megtegyenek azért, hogy ez a méltánytalan helyzet megoldódjon, de legalább is jóval kevésbé egyenlőtlen rendszereket építsenek ki. A pápa kiemeli, hogy napjainkban egész néptömegek érzik magukat kirekesztettnek és peremre sodródottnak munka, lehetőségek, kiutak nélkül. Az embert olyan árucikknek tekinti a jelenlegi gazdasági rendszer, amit használat után el lehet dobni. Ezt a pápa a „szemetes kosár” kultúrájának nevezi. „Már nem a kizsákmányolás és elnyomás egyszerű jelenségéről, hanem valami újról van szó: a kirekesztés révén gyökerében sérül az életterünkül szolgáló társadalomhoz való tartozás; már nem zátonyra futva, nem perifériára kerülve vagy hatalom nélkül élnek emberek, hanem egyenesen azon kívülre kerültek. A kirekesztettek nem „kizsákmányoltak”, hanem elutasítottak, „maradékok” (Tornielli - Galeazzi 2015: 60)." Az Evangelii gaudium kezdetű enciklikát sokan támadták, kritizálták, marxizmussal, pauperizmussal vádolták. John Grapper például, 
www. metszetek.unideb.hu

\section{TEMATIKUS TANULMÁNYOK - Menedzsment: vezetők, vezetés és munkavállalók}

a Financial Times ismert szerkesztője az apostoli buzdítás azon részét bírálta leginkább, amely a piacok abszolút autonómiáját védelmező ideológiák és a pénzügyi spekuláció ellenében foglal állást (Tornielli - Galeazzi 2015).

\section{A pénzügyi piacok hatalma}

„Korunknak mindennél inkább szembeötlő jelensége és jellegzetessége, hogy nem csupán anyagi eszközök, hanem mérhetetlenül nagy hatalom és despotikus gazdasági mindenhatóság halmozódik fel néhány ember kezében, akik többnyire nem is tulajdonosai, hanem csak kezelői és működtetői a rájuk bízott vagyontömegeknek ${ }^{3}$, amely fölött korlátlan teljhatalommal rendelkeznek. Ezt a hatalmat azok tudják a legkíméletlenebbül gyakorolni, akik a pénztőkét birtokolják és uralják, mert így fennhatóságuk alatt vannak a kamatok, uralják a hiteléletet, ennek következtében az egész gazdaság vérkeringését ellenőrzik, és olyannyira ők vezérlik a gazdaságnak ezt az éltető elemét, hogy akaratuk ellenére senki még csak lélegzethez sem juthat (Tornielli - Galeazzi 2015: 10)."

A pénzügyi piacok hatalma világszerte növekszik, ami a munka céljainak haszonelvűbb megközelítését, valamint a vagyon maximalizálását erősíti, és a rövid távú előnyöket a közjó rovására hangsúlyozza. A globalizációnak köszönhetően a tőke csaknem korlátlan szabadságra tett szert, függetlenedett az országhatároktól. A multinacionális vállalatok profitmaximalizáló stratégiájuk szerint termékeiket az egyik országban állítják elő, egy másik országban adóznak, támogatást, pályázati forrást pedig egy harmadik országban igényelnek. Amennyiben egy adott országban a működési feltételek, üzleti környezet kedvezőtlenné válik számukra (pl. munkabérek emelkednek, környezetvédelmi szabályozás szigorodik), gyakorta lépnek tovább olyan országba, ahol számukra kedvezőbbek a működési feltételek. Kibúvót jelent számukra, hogy az országok kormányai csak nemzeti szinten tudják ezen nemzeteken átívelő vállalatok működését szabályozni (támogatni, ösztönözni, korlátozni), így a működési rendjük szinte teljesen követhetetlen, gyakorlatilag autonóm (Harrington et al. 2014).

Fidrich (2002) szerint a vállalatok nemzetek feletti terjeszkedésében nagy szerepe volt többek között a világpiachoz való hozzáférésnek, valamint a 70-es évektől uralkodóvá vált neoliberális gazdaságpolitika szellemében a szabad kereskedelem

${ }^{3}$ Ezt a jelenséget a közgazdasági szakirodalom az „ügynökproblémának” nevezi, amikor is elválnak egymástól a tulajdonosi és a menedzseri szerepkörök alapvető érdekei. A jelenség központi kérdése, hogy „a tulajdonosok menekülnek az operatív irányítástól, hiszen az a hatalom mellett gonddal, bajjal, felelősséggel is jár, míg a részvényekben vagy egyéb likvid, személytelen vagyontárgyakban, „papírokban” megtestesülő pénz csak hatalom. Hozzá sem kell nyúlni, s kamatozik, osztalékot fizet, árfolyamnyereséget hoz." (Tóth 2016: 29) Kérdés, ugyanakkor, hogy a menedzser vajon mennyire lelkiismeretesen és kinek az érdekeit követve jár el a vagyon kezelésekor? 


\section{TEMATIKUS TANULMÁNYOK - Menedzsment: vezetők, vezetés és munkavállalók}

útjában álló korlátozó intézkedések (vámok, kereskedelmi kvóták stb.) eltörlésének az OECD, GATT és WTO egyezményei keretében. Ezek alapján megállapítható, hogy a II. Világháborút követően kialakult nemzetközi gazdasági pólusok (USA, EGK, Japán) száma emelkedett, új gazdasági pólusok jelentek meg a nemzetközi piacon (Kína, India stb.), melyek felülírták az addigi kereskedelmi szabályokat.

Tóth (2007) írja David Korten (1996) munkáját idézve, hogy 1991-ben a világ 100 legnagyobb gazdaságából 50 tôkés társaság volt, valamint a 10 legnagyobb tőkés társaság összesített kereskedelmi forgalma meghaladta ugyanebben az évben a világ 100 legkisebb országának összesített GNP-jét. Kritikaként hozzáteszi azonban a szerző, hogy írásában nem jelentette meg Korten a listát, amiről megállapításait megfogalmazta. Egy új listát állított össze Tóth (2007) az IMF és a FORBES 2005ös adatai alapján. Ebből az derül ki, hogy a világ 100 legnagyobb gazdasága között 58 nemzetállam és 42 vállalat (nemzetközi vállalatcsoport) helyezkedett el. Kiemeli, hogy a British Petrol éves forgalma nagyobb volt, mint például Finnország vagy Görögország éves GDP-je, valamint azt, hogy az alapvető élelmiszerek piacának 7090\%-át 4-5 vállalat kontrollálta. A 150 legnagyobb gazdaság vonatkozásában már egyértelmúen a vállalatok voltak túlsúlyban, azaz 83 vállalat és 67 nemzetállam szerepelt a listán. 2016-ban a világ 100 gazdasági nagyhatalma között már 70 vállalatot találunk és csak 30 nemzetállamot. A nagyvállalatok aránya növekvő tendenciát mutat, 2015-ben számuk 63 volt a top 100-as listán (Green 2016). Hozzá kell azonban tennünk, hogy a hivatkozott 1991-es, 2005-ös és 2016-os számadatok más-más forrásból származnak, de a vállalatok növekvő gazdasági erejét és így a nemzetközi tendenciát is elég egyértelműen körvonalazzák.

\section{A gazdasági tevékenység értelme}

Ahhoz, hogy megértsük a jelenleg uralkodó gazdasági rendszer (számunkra kedvezőtlennek tartott) tulajdonságait, röviden tekintsük át az ezt meghatározó főbb fogalmakat. Korunk értelmezése szerint a 'gazdálkodás' a minél nagyobb profit, haszon és jólét érdekében végzett tevékenységeket összesíti. Idegen nyelvű megfelelője, az 'ökonómia' a Magyar Nyelv Értelmező Szótára szerint közgazdaságtant, valamint a javakkal való ésszerü, takarékos gazdálkodást jelenti, melynek célja a vagyon, tulajdontárgyak célszerủ elrendezése, elosztása (Internetes hivatkozás 1.). A kifejezés az 'ökosz' ógörög szóból ered (görögül 'oikos'), mely ház, háztartás, házigazdaság, család, családi gazdaság jelentéssel bírt (Internetes hivatkozás 2.). Vegyük észre, hogy egyik szó jelentésében sem jelenik meg a növekedésre, gyarapodásra, többletre való törekvés vagy hajlam, a cél mindössze a javakkal való gazdaságos, racionális bánásmód.

Az ökonómia eszerint való értelmezése közel 2000 évig volt jellemző a közgazdaságtanban, majd az „utilitárius fordulatot” követően a haszonelvüség szemlélete 


\section{TEMATIKUS TANULMÁNYOK - Menedzsment: vezetők, vezetés és munkavállalók}

vált irányadóvá. ${ }^{4} \mathrm{Az}$ utóbbi két-háromszáz évben a gazdasági-társadalmi folyamatok vezérfonalává az ökonomizmus vált. Erről akkor beszélhetünk „ha a gazdaságosságra, hatékonyságra, versenyképességre való törekvés már nem az emberi haladást szolgálja, hanem öncélként jelenik meg (Tóth 2016: 30)." Míg az ökonómia célja a jólét hosszú távon való elérése, szolgálata volt az egész közösség számára, a javak beosztó felhasználásával, addig az ökonomizmus a gazdasági cselekedetek szúken vett érintettjeinek rövid távú hasznát veszi számításba, ezáltal támogatva a javak korlátlan felhalmozását (ibid). Az ökonomizmus tehát fetisizálja a gazdaságosság jelenségét, a nyereség és haszon maximalizálását tartva egyedüli elvként szem előtt. A haszonelvű gazdaságtan vezérfonala tehát elsősorban a verseny, a nyereség és a haszon fogalmak mentén szerveződik, amit Schumacher 'A kicsi szép' című művében így fogalmaz meg: „Az elmarasztaló ítéletek mai tárházában kevés szónak van olyan lesújtó és döntő jelentése, mint a „gazdaságtalannak”. Ha egy tevékenységre rásütötték a gazdaságtalanság bélyegét, nemcsak hogy kérdésessé vált a létezéséhez való joga, de egyszer s mindenkorra el is vesztette azt. Amiről egyszer kiderült, hogy gátolja a gazdasági növekedést, az szégyenletes dolog, és ha valaki mégis ragaszkodik hozzá, azt vagy szabotőrnek, vagy őrültnek tekintik (Schumacher 1991)."

\subsection{A KÖZJÓ ÉRTELMEZÉSE}

A közgazdaság tehát kezdetben a javakkal való ésszerű gazdálkodást jelentette, mai értelmezésében mégis nagyobb szerepet kap a haszon és profit maximalizálására való törekvés. De vajon mi változott időközben? Hogyan és miért módosult a cél? A magyarázatot a "közjó” fogalmában érhetjük tetten, amelynek elérése a 'köz' gazdaságának eredeti motivációja volt. A (köz)jó fogalma - mint látni fogjuk - kulcsszereppel bír a gazdasági rendszerek jellemzőinek beazonosításakor is.

A Magyar Nyelv Értelmező Szótára szerint a közjó „a közösség, a társadalom érdeke, java, boldogsága, jóléte, ill. mindaz, ami ezt elősegíti, előmozdítja (Internetes hivatkozás 3.)." A közjó tehát minden ember érdeke, csak közösségként érhetjük el, egymással együttmúködve, emberi mivoltunkban kiteljesedve.

A közgazdaság (ökonómia) kifejezés Arisztotelész nevéhez köthető. Az ő gazdasági elmélkedéseinek fókuszában is a 'jó' keresése állt, amire szerinte minden emberi cselekedet irányul. Meggyőződése volt, hogy az ember számára a 'legfőbb jó' a boldogság, minden ember célja, hogy megtalálja a legnemesebb boldogságot, ezt elérni pedig csakis az erényeken keresztül lehetséges. Etikáját ezért erényetikának is nevezik (Internetes hivatkozás 4.). A gazdálkodással, vagyonszerzéssel kapcsolatban kétféle utat különböztetett meg: a „természetes gazdagság” a helyes életre

${ }^{4}$ Az utilitarizmusról részletesebben a 3. fejezetben olvashatunk. A témáról kiváló összefoglaló ad Tóth Gergely Gazdasággép (2016) című könyve. 


\section{TEMATIKUS TANULMÁNYOK - Menedzsment: vezetők, vezetés és munkavállalók}

törekszik, ennek célja a boldog (értsd: jó) élet szempontjából elégséges mennyiségű vagyon megszerzése, mely elengedhetetlen a család, a közösség és a városállam boldogulása végett. A vagyonszerzés telhetetlen, öncélú művelése, amelyet „mesterséges gazdagságnak”, „pénzkeresésnek” nevez, azonban elítélendő, a vagyon határtalan gyarapítása nem vezet igazi boldogsághoz. Ebből a gondolatmenetből kitűnik, hogy az ökonómia a jó elérése szempontjából fontos és hasznos (szükséges és elégséges) jelenség, azonban ezen túl nincs hozzáadott szerepe a boldogság megtalálásában (Arisztotelész 1984). Hasonló gondolatokat fogalmaz meg Arisztotelész a kereskedelemmel kapcsolatban is: addig, amíg a vagyontárgyak cseréje az önellátást szolgálja az támogatandó és helyes, attól kezdve azonban, hogy az a vagyonszerzésre és pénzhalmozásra összpontosít, természetellenessé válik, amely akadályozza az emberek magasabb erényeinek kialakulását, telhetetlenné tesz, aláássa a közösségi életet, politikai egyenlőtlenségeket szül, röviden gátolja a jó elérését.

Aquinói Szent Tamás, a középkor karizmatikus bölcselője Arisztotelész filozófiájából kiindulva igyekezett azt összhangba hozni a keresztény tanítással, kísérletet téve egy átfogó filozófiai rendszer felállítására. Szent Tamás számára „a jó az, ami a másik számára tökéletesedést képvisel, s így törekvésének a célja. A jó az, amire minden ember érdeklődése irányul. Az ember legfőbb célja a boldogság (Internetes hivatkozás 5.)." Túllépve tehát az arisztotelészi hitvalláson a legfőbb jónak azt az állapotot tartja, ami a személyes érdekeken túl mások jó(l)létét is szolgálja - jóllehet Szent Tamás ezt is önérdekként definiálja. Más szavakkal: „az jó nekem hosszú távon, ami a közösségemnek is jó, s már középtávon sem éri meg potyautasnak lenni (Tóth 2016: 59)." Ez a közösségi szemlélet érhető nyomon a kereskedelemről és a cseréről alkotott gondolataiban is. Ezek szerint a csere csak abban az esetben ildomos, ha mindkét félnek haszonnal jár és az üzlet méltányos áron köttetik.

A közjó értelmezésénél érdemes még megemlítenünk Bernard de Mandeville holland származású orvos és író gondolatait, aki a „dicsőséges forradalom” és az ipari forradalom közötti időszakban élt Angliában. Politikai röpiratként jelent meg az 1690-es évek végén 'A lázongó kas avagy a megjavult gazemberek' c. írása. Második kiadására 1705-ben került sor, azonban visszhangot még nem igazán keltett. 1714-ben, majd 1723-ban 'A méhek meséje' címmel került ismét kiadásra, ekkor azonban már elméleti fejtegetéssel egészíti ki parabolisztikus meséjét a szerző, ami immár igen nagy port kavart fel. Korának társadalmi, gazdasági folyamatait, értékrendjét egy méhkas működésére vetíti le. „Ha panaszkodsz, hát balga vagy: tisztes kas hogy lehetne nagy? A világ javaival élni, harcban győzni, közben henyélni s bűnt kerülni: utópia, gyarlóbbat agy nem szült soha... Puszta erénytől nem virágzik föl egy nemzet; s ki visszavágyik az aranykorba, kész e vajon élni becsületben - de makkon (Mandeville, 2004: 24)?” Műve alapvetően etikai és antropológiai fejtegetésekből áll, ami a közjó a magánbűnök szülötte paradoxonára épül. Az egyéni vétkek gazdasági szempontból a társadalom javára válnak, végső soron tehát - a közösség szem- 


\section{TEMATIKUS TANULMÁNYOK - Menedzsment: vezetők, vezetés és munkavállalók}

pontjából - hasznosak „Mi teszi naggyá, hatalmassá, legyőzhetetlenné az államot? A gazdagság. Milyen erkölcsi tulajdonságok járulnak leginkább hozzá a gazdagodáshoz? A rosszak. Ez tehát annyit jelent, hogy a bűnök - gazdasági vonatkozásban - értékek (Heller 2004: 239-240)."

\section{Az utilitarizmus és kritikája}

Jeremy Bentham angol filozófus és jogbölcselő (1748-1832) a hasznosságot és az érdeket az élet és az életvitel alapelvévé tevő etikai irányzat (utilitarizmus) megalapítója. Számára valamely jogi politikai intézmény hasznossága attól függ, hogy az a bizonyos intézmény mennyiben mozdítja elő a legtöbb ember lehető legnagyobb fokú boldogságát. Hangsúlyozta, hogy a hasznosság-elv a gyakorlati életben ténylegesen alkalmazható, megadható a kalkulus, melynek segítségével bármely két tettről eldönthető, hogy melyik hasznosabb. Szerinte az egyéni hasznosság - még ha bűnök formájában is - a közjóhoz vezet (Csapóné 2008).

A gazdaság morálökonómiai értelmezése az 1700-as évek közepéig tartotta egyeduralmát a világon. A fordulópontot Adam Smith, „a közgazdaságtan atyjának” sokat idézett könyve okozta, amikor is a „Nemzetek gazdagsága” (1776) című művében megfogalmazza a 'láthatatlan kéz' jelenségét. A költői kép arra az önműködő erőre utal, amely meglátása szerint akarva-akaratlanul elrendezi (és a lehető leghatékonyabb állapotot eredményező módon rendezi el) a piaci viszonyokat, amennyiben a gazdaság szereplői saját érdeküket követve cselekednek a különböző tranzakcióik során. Ettől számítjuk a korábban említett „utilitárius fordulatot”, amelynek további kulcsfigurái Bentham és John Stuart Mill voltak. A haszonelvű gazdaságtan ettől kezdve napjainkig domináns pozíciót vívott ki magának mint gazdasági paradigma.

Az utilitarizmus az erkölcsfilozófia egyik legjelentősebb ága, melynek központjában az egyén önérdekkövetése áll. A haszonökonómia elveinek megtestesítője a homo oeconomicus-nak nevezett embertípus, aki célja, hogy cselekedetei útján maximálja saját hasznosságát, élvezetét, boldogságát. A boldogság, és a jó keresése, mint alapelv tehát ebben a filozófiában is jelen van, a gazdaság átfogó célja pedig „a lehető legnagyobb boldogság elérése a lehető legtöbb ember számára”. ${ }^{5}$ Bentham szerint a lehető legnagyobb számú élvezet kiszámításához „azoknak a fájdalmát és gyönyörét is be kell kalkulálnunk, akiket majd érint a cselekedetünk. Vagyis nem érdemes a saját hasznunkat mások haszna elé helyeznünk, mert az élvezetek és fájdalmak kalkulációjából akár az az ítélet is születhet, hogy nekem kell lemondanom az élvezetről, hasznokról, mert ezzel mások nagyobb 'boldogsághoz' jutnak." (Szabó 2017: 188) Hasonló gondolatokat fogalmaz meg Mill is, aki szerint a legnagyobb ha-

${ }^{5}$ Az eredeti kifejezés Beccaria, olasz jogtudóstól származik, „La massima felicita divisa nel maggior numero" (Bentham 1977) 


\section{TEMATIKUS TANULMÁNYOK - Menedzsment: vezetők, vezetés és munkavállalók}

szon elérésére akkor képes az ember, ha „elsősorban mások javát keresi, a saját élvezetét pedig csupán annyiban, amennyiben az szükséges életének és képességeinek fenntartásában (Szabó 2017: 195)."

A boldogság keresése és a félelemtől való megszabadulás vágya mellett az önmeghaladás képessége is természet szerint jellemzi az embert. A három alapvető emberi adottság közül ez utóbbi testesíti meg leginkább az ember társasági (közösségi) voltát, amely szerint a szigorúan vett önérdekkövetés mégsem mindig kielégítő. Egy ponton belátjuk, hogy mások boldogsága a saját boldogságunkra is visszahat, sőt, annak eredője lehet, ezért mások boldogságáért tenni úgy is kívánatossá válhat, hogyha ezzel adott esetben a saját érdekeimen túl, vagy azzal szemben kell cselekednem (Tóth 2017).

A haszonelvư gazdaságot irányító utilitarizmus így látszólag mégis szolidáris a közzel szemben. Talán a közgazdászok egy része sincs tisztában azzal, hogy a haszonelvú gazdasági paradigma igenis számol a másik emberrel, tervez vele, számításba veszi szükségleteit! Az általános (ámde téves) definíció szerint az utilitarista felfogás pusztán önérdekkövetést jelent, amelyben az önző szereplő egy esemény lehetséges kimeneteleit pusztán magára vonatkoztatva szemléli. Ennek oka Fromm szerint az lehet, hogy az objektív önérdek mint korábbi közfelfogás, amely figyelembe vette a közösség érdekeit is, az elmúlt háromszáz évben szubjektív önérdekké, kvázi önzéssé degradálódott. Amiről ma valaki azt gondolja, hogy összhangban van saját érdekével, az innentől kezdve valós önérdekévé is válik (Fromm 1975).

Valós kritikaként róható fel a filozófiának, hogy a közösség legnagyobb hasznát keresve az egyéni érdek, így maga az ember feláldozhatóvá válik a „köz oltárán”, amennyiben ezzel teljesül a legnagyobb hasznosság állapota. A haszonökonómia eszmeiségében ez védhető érvelés, jóllehet súlyosan sérti az emberi méltóság elvét, amely tagadja, hogy az embert csupán eszköznek tekintve „szükséges veszteségként" írhatnánk le a célért vívott harcban. Problémás továbbá, hogy a többség érdeke minden esetben felülírja a kisebbség érdekeit, hiszen azok veszélybe sodorják a legnagyobb jólét elérését, még akkor is, ha erkölcsileg a kisebbségnek van igaza.

A homo oeconomicus-sal mint a haszonelvű gazdaság emberi prototípusával kapcsolatban is megfogalmazhatók ellenérvek. Az önző emberi magatartást axiómaként kezelni súlyos hiba. Míg bizonyos tudományokban léteznek megkérdőjelezhetetlen szabályok, az emberi természet nem determinisztikus jellegú. A gazdasági életben legjobb esetben is törvényszerűségekről beszélhetünk, ami merőben eltér a természettudományok törvényeitől (Muzslay 1995). Ez számunkra annyit jelent, hogy még ha a kapitalista szemlélet és a globalizációs folyamatok erősödése eredményeképpen ma valószínúleg tényleg önzőbb az emberi viselkedés, mint száz vagy ezer évvel ezelőtt, ezt akkor sem jelenthetjük ki kétségek nélkül. Baranyi ezzel kapcsolatban a következőket írja: „Az ember önző voltát abszolút érvényes kiindulópontként kezelő nézet esetén tehát tetten érhető a mögötte meghúzódó ideológia, 


\section{TEMATIKUS TANULMÁNYOK - Menedzsment: vezetők, vezetés és munkavállalók}

amelynek képviselője nem akarja felfedni, hogy állításai valójában nem megfellebbezhetetlen természettudományos tényeken, hanem meghatározott antropológiai előfeltevéseken nyugszanak (Baranyi 2017: 331)."

Az utilitarista szellemiség terjedése magával hozta a legnagyobb élvezetek, boldogság pénzben történő mérését, amely a közgazdaságtan keretein belül magától értetődő volt. A pénz megkönnyítette az előnyök számszerűsítését, a különböző alternatívák összehasonlítását gyakorlati és könnyen kezelhető eszközt szolgáltatva a döntéshozóknak. Innen már egyenes út vezetett ahhoz, hogy egyes tevékenységek hozadékát különböző pénzügyi mutatók segítségével mutassák ki, és a nyereség-, haszon- és profitmaximalizálás motivációja dominálja a gazdasági folyamatokat. Ez a szemlélet túlságosan lesarkítja a gazdasági döntéshozatalt, főleg, ha visszagondolunk Arisztotelész kiindulópontjára és emberi értékeket, erényeket keresünk benne. „S bár az utilitarizmus nem állítja tételesen, hogy a pénz lenne a boldogság elsődleges forrása, a gyakorlatban mégis első helyre teszi, hiszen a dolgokat szigorúan a gazdasági-társadalmi hasznosság szempontjából nézi. Így lehetséges az, hogy az egészség, a tanítás, és egyáltalán az élet a társadalom számára kiadások és bevételek alapján nyer kifejezést (Szabó 2017: 197)."

Ezeknek a tényezőknek a számszerűsítése azonban nem egyszerű folyamat. Ezért a közgazdászok között egyre inkább elfogadott nézet, hogy különbséget tesznek a jólét és a jóllét fogalmai között. A jólét (angolul well-fare) klasszikus gazdasági fogalom, amit a jóllét (angolul well-being) olyan tényezőkkel egészít ki, mint a fentebb felsorolt egészség, hosszú élet, családi és baráti kapcsolatok, a közösség ereje, kulturális értékek, stb., melyek pénzben nehezen mérhetőek. A pénz mint mérce mindenhatósága ellen szól az is, hogy régóta közismert tény, hogy az anyagi javak többlete egy bizonyos ponton túl nem nyújt nagyobb boldogságot tulajdonosának. Ezért is fordulhat elő, hogy a világ országainak boldogság rangsorában mégis az első 50 között szerepel Costa Rica, Chile, Guatemala, Trinidad és Tobago és Üzbegisztán (Internetes hivatkozás 6.). A közgazdaságtan „Easterlin-paradoxonként” hívja azt a jelenséget, amelyben a névadó közgazdász megcáfolja azt a null-hipotézist, miszerint a gazdagabbak természetszerűen boldogabbak is. Bár eredményei szerint valóban létezik a két tényező együttállása, de oksági kapcsolatról nem beszélhetünk. A gazdasági növekedés nem szükségszerűen növeli az emberek boldogságérzetét, részben azért, mert az „abszolút jövedelem” nagyságán túl fontosabb a „relatív jövedelem" szintje, amelyet pszichológiai mechanizmusok magyaráznak, mint például a saját helyzetünk másokéval való összehasonlítása, valamint bizonyos (pozitív vagy negatív) események beépítése az értékalkotás folyamatába (Easterlin 1974). 


\section{TEMATIKUS TANULMÁNYOK - Menedzsment: vezetők, vezetés és munkavállalók}

\section{A „status quo”}

A XIX. századtól kezdve a pénzügyi szemlélet vezérelte gazdaság egyeduralma ténykérdés, látjuk azonban, hogy számos rés üthető a pajzsán. Tóth Gergely (2017) szerint a második világháború utánra a morálökonómia „hattyútáncát” járja, bár elismeri, hogy számos emberközpontú kezdeményezés, mint a minimálbér, a szakszervezetek felállítása, a modern munkajog intézménye, a környezettudatos vállalatirányítási rendszerek, vagy a társadalmi felelősségvállalás már legitim fogalmak. Mégis, amikor a közgazdaságtan modellszerű rendszerében gondolkodunk, egy durván leegyszerűsített, csupán a tőke és a munka termelési tényezőkre koncentráló keretben gondolkodunk. A haszonökonómia uralma mellett „alternatív iskolának” számít bármi, ami nem a gazdaságosság és versenyképesség elveit hirdeti.

Elmúlt, darabjaira hullott az a korábban érvényben lévő közfelfogás, ami a gazdasági-társadalmi kapcsolatokat tudat alatt is irányította. A közös szemlélethez márpedig elengedhetetlen egy olyan mindenki által elfogadott és követett erkölcsi-etikai mérce, amely által megítélhető egy cselekedet minősége, pozitív vagy negatív előjele. Közös álláspont vagy közmegegyezés nélkül a békés társadalmi együttélés csupán utópia. A jelenségről Baranyi így ír: „Az európai politikai gondolkodásmód és közmorál - nagyrészt a magát „felvilágosodásnak” nevező eszmeáramlat eredményeként - megfosztotta magát az alapvető bizonyosságok forrásától: a bibliai keresztény alapoktól. A nyugati civilizáció országaiban ugyan továbbra is elismerik az etikai normákat és hangoztatják fontosságukat, azonban e normák eredeti közegükből kiragadva talajvesztetté, észszerűen alá nem támaszthatókká váltak (Baranyi 2017: 334)." A globális (üzleti) folyamatok által támogatott változás azt eredményezte, hogy a társadalom alrendszerei (család, gazdaság, politika-jog, kultúra-vallás, tudomány) eltávolodtak egymástól és külön életet kezdtek élni. Ennek legnagyobb veszélye, hogy egy olyan állapotba kerül a társadalom, ami már nélkülözi a közösen vallott értékrendet, a korábban elfogadott és betartott keretrendszer értelmét veszti és semmivé lesz. Ebben az állapotban az alrendszerek nem képesek már a közjót szolgálni, ami pedig minden társadalom célja lenne, a társadalometika - mint irányító központ - eszköztelenné válik. Érdekellentétek lépnek fel a különböző alrendszerek között (pl. egy üzletkötés emberi, környezeti vs. gazdasági megfontolásai közt), ami hosszú távon társadalmi-ökológiai válsághoz vezethet. Végül az etikai normák (köz)elfogadásának hiánya olyan állapothoz vezet, melyben „szabadon megtehető szinte bármi, ami az adott részrendszer logikájának megfelel, még akkor is, ha az homlokegyenest ellenkezik a közjóval (Baranyi 2017: 335)." Így történhet meg, hogy bizonyos cselekedetek bár etikátlanok, mégis teljesen jogszerűek. Kérdés, hogy ez a fejekben-lelkekben erős disszonanciát eredményező lelkiállapot meddig tartható fenn? Hogyan lehetséges olyan társadalmakban élni, amelyekben a cselekedetek megítélése nem egységes? Az „egyetlen közös elv, hogy nincs közös elv” nem 
www. metszetek.unideb.hu

\section{TEMATIKUS TANULMÁNYOK - Menedzsment: vezetők, vezetés és munkavállalók}

elégséges rendezőelv, az eszmei vákuumot valami más, valami új paradigmának kell betöltenie (Baranyi 2017).

\section{A menedzsment fejlődése - motivációs elméletek}

A menedzsment tudományos elméletei nagy fejlődési utat tettek meg az elmúlt száz évben. A mérföldköveknek tartott tudományos munkák mindegyike (Taylor 1911, Mayo 1933, Maslow 1943, McGregor 1960, Herzberg 1966, Hackman - Oldham 1975, Csíkszentmihályi 1990, Pink 2009 In Szilas 2017) konzisztens emberképpel rendelkezik, amelynek része a munkához való hozzáállás is. Anélkül, hogy részletes és teljes körű áttekintést adnánk ezekről a munkákról, Szilas (2017) írása alapján ismertetünk a továbbiakban pár érdekes elméletet.

A taylorizmus legnagyobb eredménye a tudatos munkaszervezésben érhető nyomon. Taylor a munkafolyamatok szervezésének leghatékonyabb módját szerette volna tudományos alapokra helyezni, ennek érdekében elválasztotta egymástól a szellemi és fizikai munkavégzést a teljesítmény mérhetősége és ellenőrizhetősége céljából, valamint hangsúlyozta az anyagi motiváló tényezők fontosságát. Ez a munkát végző embert „lebutítva” ábrázolja, aki számára legfontosabb ösztönző a pénz. A munkavállalókon keresztül, a pénz által (mint korábban láttuk) relatív egyszerü a szervezet működtetése, az érzelmeket nélkülöző, racionális döntéshozatal során az embereket pusztán termelési tényezőnek (eszköznek) használva kell megfelelni a hatékony munkaszervezés elvárásainak. Taylor szerint az anyagi juttatások szerepe a munkavállaló motiválásában kizárólagos jellegű, és az embert egyáltalán nem érdekli a munkavégzés eredménye, vagy jellege. Bár az anyagiak fontosságában nem tévedett, az ebből levezetett egysíkú gondolkodás, és a „tökélyre fejlesztett”, „leghatékonyabb" részfeladatok sokszor embertelen volta miatt mégis 'redukcionista' jelzővel illetik emberképét. A Human Relations mozgalom képviselői (Mayo, Maslow, Bernard és mások) nem osztották Taylor nézőpontját. A legkimunkáltabb emberképet McGregor 1960-ban írt művében, a „The Human Sides of Enterprise”-ban ismertette, amelyben az X és Y elméletében kifejti az emberi természet és ezzel együtt a vezetői szemlélet két merőben eltérő típusát. A X elmélet hasonlít a taylori emberképre, ennek értelmében a vezető beosztottját lusta és felelőtlen embernek tekinti, akit leginkább csak az anyagi juttatásokkal, büntetéssel, valamint rendszeres ellenőrzésekkel és szigorú elszámoltatással lehet munkára késztetni. Ezzel szemben az Y elmélet vezetői alapfeltevése az, hogy az ember szellemi kihívásokat keresve, örömmel dolgozik, a munkafeltételek rendelkezésre állásakor feladatát önállóan, felelősen és kreatívan látja el. Bár számára is fontos az anyagi megbecsülés, nem ez a fő motiváló erő a munkavégzésre. „A McGregor által felvázolt gondolatmenet talán legjelentősebb eleme a vezető emberképre vonatkozó választásának és az ebből fakadó 


\section{TEMATIKUS TANULMÁNYOK - Menedzsment: vezetők, vezetés és munkavállalók}

felelősségének a hangsúlyozása. Az X vagy Y elmélet szerinti alapfeltevések az emberi természetről és az ebből fakadó menedzseri gyakorlat egyfajta önbeteljesítő jóslatként működnek (Szilas 2017: 415).” Az „amilyen a hited, úgy legyen neked” szemléletnek megfelelően tehát a vezető képes befolyásolni munkavállalója hozzáállását, s felszabadítva őt az emberi természet (itt: gyarlóság) eleve elrendelt állapota alól megteremti a szabad utat a kreativitásnak, önmegvalósításnak és a felelős munkavégzésnek. Az önként vállalt és örömteli munkavégzést ösztönzi továbbá a közösségi életben való részvétel és a munka tartalmának, eredményének fontossága is. A menedzsment szakirodalom későbbi képviselői is egyetértenek ezzel a pozitív hozzáállással. Maslow szerint az ember motivációinak legmagasabb szintjén az önmegvalósítás, kiteljesedés iránti vágy áll, amelyhez például a hivatásként végzett munkán keresztül vezet az út. Herzberg motivációelméletében a pénz csak a munkavállaló elégedetlenségének elkerülésére való, (és bár ezt 'motivációs tényezőnek' hívja), a munkavállaló igazi elégedettségét elérni az úgynevezett 'higiénés tényezőkkel' lehet. Ezek a tényezők a munka lényegi tulajdonságaihoz, tartalmához kapcsolódnak, úgymint a munka kihívás jellege, érdekes volta, a munkavállaló kompetenciáinak megfelelő feladatok, valamint az önálló munkavégzés és a fejlődési lehetőségek.

Említésre méltó még Hackman és Oldham 1975-ben publikált „munkaköri jellemzők” modellje, melynek kritikus pontja a „munkakör-gazdagítás” elve. Ennek kapcsán hangsúlyozzák mennyire fontos a munkavállaló számára, hogy az általa végzett munka értelmes legyen és létezzen kézzel fogható eredménye. Bár akkoriban ez az újdonság erejével hatott, az azóta eltelt 40 év alatt a menedzsmenttudomány mára alapvetésként kezeli a munkavállalók erre irányuló elvárását ${ }^{6}$. A munka értelme és eredményessége iránti igényben ismét felismerhetjük az önmeghaladás alapvető emberi képességét, amit jóllehet a haszonelvű gazdaság igyekszik elnyomni. A mai „mainstream” menedzsmenttudomány joggal hangsúlyozza a tudatos vezetői értékalkotást, amely emberképe szerint a felelős munkavállalók önös anyagi és egyéb érdekeiken túl szeretnének egy magasabb rendű cél érdekében, a „köz” javára is cselekedni a munkavégzésük által/során (Szilas 2017).

A tömören felvázolt fejlődési út rávilágít arra, hogy a menedzsmenttudomány száz év alatt túllépett a (bántóan) leegyszerűsítő taylori modellen és mára egy „többdimenziós" emberképre való nyitottság jellemzi (Szilas 2017: 417)." A fenti elméletek pedig egyre közelebb vezetnek bennünket a humanista jellegű keresztény szemlélethez, amely a Bibliára támaszkodó társadalometikában gyökerezik.

${ }^{6}$ További utalások Perez Lopez (1991), Alford és Naughton (2001), Seligman (2002), és Pink (2009) munkáiban találhatóak (Szilas 2017). 


\section{TEMATIKUS TANULMÁNYOK - Menedzsment: vezetők, vezetés és munkavállalók}

\section{Merre tovább? - Keresztény társadalmi elvek az üzleti életben}

Már fentebb hangsúlyoztuk mennyire fontos a társadalom működőképessége szempontjából, hogy létezzen egy mindenki által elfogadott, közös erkölcsi alap, ami vezérelvként szolgál az élet minden területén. A társadalometika célja ezzel, hogy segítse az igazságos és közjót szolgáló döntések meghozatalát. A keresztény alapokkal bíró társadalometika a Felvilágosodás koráig szolgált iránytűként, ettől kezdve azonban egyre inkább vesztett népszerűségéből. Ez a törés - nem véletlenül - egybeesik az Adam Smith nevéhez köthető, a haszonelvűséget hirdető gazdasági paradigmaváltással is.

A keresztény társadalometika régen és most is a bibliai tanításokon nyugszik, a társadalom aktuális kérdései mellett a szervezeti kérdésekre és az egyéni kihívásokra is a Biblián keresztül keresi a választ. Az egyén szerepe megkérdőjelezhetetlen a folyamatban, alkotó (atomszerü) szerepe a társadalomban kulcsfontosságú. Muzslay István, a Leuveni Katolikus Egyetem közgazdász professzora erről a következőket írja: „Korunk egyik súlyos tévedése az a felfogás, hogy a közgazdaság az életünk olyan adottsága, amellyel szemben tehetetlenek vagyunk, hogy a gazdaság a saját mechanizmusainak, kérlelhetetlen törvényeinek alávetett folyamat. A közgazdaság nem fizikai törvények által irányított gépezet, a társadalmi és gazdasági rend megteremtője nem a piac ármechanizmusa, hanem az emberi értelem és akarat (Muzslay 1995: 9)." Vagyis korunkban a domináns nyereségmaximáló gazdasági szemléletre hivatkozni és a piac farkastörvényeire mutogatni az erényes és emberséges cselekedetek helyett gyengeségre vall. Mindig az ember az, aki dönt és ezzel valamilyen érték mellett teszi le a voksát. Tévedés lenne azonban azt hinnünk, hogy pusztán az egyéni cselekedeteken keresztül megoldhatjuk a XXI. század morális kihívásait. „Nem lehet pusztán egyéni cselekvéssel megoldani társadalmi szintű problémákat, mert a társadalmi szint az egyéni szinthez képest új minőséget, önálló, magasabb szerveződési egységet képvisel a struktúrák, a hálózatok, a tovagyűrűző, illetve szinergikus hatások miatt (Baranyi 2017: 330).” Ugyanez visszafelé is igaz. A Katolikus Egyház Kompendiuma szerint „Az a társadalom, amely az együttélés minden szintjén maradandóan az embert akarja szolgálni, a közjót mint minden ember és az egész ember javát jelöli meg elsőséget élvező céljaként. A személy saját magában, figyelmen kívül hagyva, hogy lényének legfontosabb eleme a másokkal és másokért való létezés, nem képes megtalálni teljességét (Internetes hivatkozás 7.)."

A Római Katolikus Egyház társadalmi tanításai további ajánlást tesznek a témával kapcsolatosan. Az angolul Catholic Social Thought vagy Teaching címmel jelölt írások az elmúlt 120 évben születtek meg, amelyben az éppen regnáló Pápa a kor kihívásaival kapcsolatos gondolatait osztja meg olvasóival ${ }^{7}$. „A katolikus társadalmi

\footnotetext{
${ }^{7}$ Összefoglalásukat lásd Tóth (2016) 7.5. fejezetében.
} 


\section{TEMATIKUS TANULMÁNYOK - Menedzsment: vezetők, vezetés és munkavállalók}

tanítást ${ }^{8}$ az Egyház szociális enciklikái (körlevelei) ismertetik, melyek az adott időszak aktuális társadalmi kérdéseiben kívántak és kívánnak iránymutatást adni a társadalmi kérdésekre fogékony, azokért tenni akaró keresztények, hívők és nem hívők számára (Kék 2017: 210)." Ezek a körlevelek nem dogmatikus, minden hívőre nézve kötelező érvénnyel bíró elvárások, hanem ajánlások, amely által az erre fogékony olvasó könnyebben össze tudja hangolni hitét a hivatásával a társadalom különböző - így a gazdaság - területén is. Az egyház társadalmi tanításai számos témában foglalnak állást (politika, jogok, alapelvek, család, munka, környezet, béke, stb.), ezek közül a gazdaság különös fontossággal bír. Tóth Gergely 'Gazdasággép' (2016) című könyvében hozzávetőleges becslést készít, amely szerint az eddig megjelent 17 pápai körlevél tartalma 62 százalékban tartalmaz gazdaságelméleti jellegű utalást. A legelső 'Rerum novarum' kezdetű, 1891-ben publikált apostoli írásban XIII. Leo arra hívja fel a papság figyelmét, hogy kötelességük a legfontosabb társadalmi kérdésekben állást foglalniuk és amennyiben ez lehetséges, kivenni a részüket a kérdések rendezésében. (Ettől kezdve rendszeresen jelennek meg egy adott témát boncolgató enciklikák.) Ezzel együtt azonban fontos megjegyezni, hogy „, katolikus Egyház egyrészt nem kíván sem a politikába, sem a gazdasági-pénzügyi életbe illetéktelenül beleavatkozni, hiszen tiszteletben tartja az egyes tudományok autonómiáját, másrészt nem kíván konkrét megoldási javaslatokat előírni a felmerülő társadalmi-közösségi problémákkal kapcsolatban. Amit meg kell tennie (...): le kell fektetnie az emberi együttélésben fontos alapelveket és nevükön kell neveznie az értékeket (Kék 2017: 217)." Ezek az értékek nyújtanak támaszt a gazdasági döntések meghozatalakor is.

Az Egyház tanítása szerint több ilyen alapelv is van, ezek közül esetünkben kiemelkedő a (korábban már sokat tárgyalt) közjó szolgálata, az emberi méltóság tisztelete, a szubszidiaritás, és a szolidaritás elve.

A Magyar Katolikus Lexikon a közjót így definiálja „(lat. bonum commune): anyagi és szellemi javak és lehetőségek összessége, amelyek szükségesek ahhoz, hogy egy közösség tagjai boldogulásukat szabadon és hathatósan munkálhassák, de előállításukra önmagukban, egyenként nem képesek. Lényegét tekintve a társadalom által saját tagjainak nyújtott segítség alapvető életfeladataik teljesítéséhez (tehát társadalmi teljesítés és nem az egyéni javak és sikerek összessége) (Internetes hivatkozás 8.)."

Az emberi méltóság tisztelete az ember istenképmási státuszából ered, emiatt az emberi méltóság megkérdőjelezhetetlen. Az embert, mindig mint valakit, nem mint valamit kell számításba venni! Ezen elv értelmében a munkavállaló sokkalta több

${ }^{8}$ A témának nagy szakirodalma van, mi itt csak a katolikus egyház társadalmi tanításaival foglalkozunk. Max Weber 1920-as publikációja óta növekvő érdeklődés övezi az egyház (nála a protestáns) és tanítása gazdaságra gyakorolt hatását. 


\section{TEMATIKUS TANULMÁNYOK - Menedzsment: vezetők, vezetés és munkavállalók}

mint eszköze a munkának. Gondolatai, érzései lehetnek és vannak ezzel kapcsolatban, amit a munkaadójának figyelembe kell vennie.

A szubszidiaritás elve szerint a társadalom központosított irányítása nehézkes és pontatlan, ezért „az alacsonyabb szervezeti szinten jelentkező problémát, végrehajtandó feladatot a probléma szintjén kell megoldani (Kék 2017:211)." Ez jogokat és kötelezettséget is jelent az adott szint számára, ami, ha úgy érzi mégsem boldogul a rá bízottakkal, segítséget kérhet (és kap is) a felettes szinttől. A szubszidiaritás többet jelent a feladatok egyszerű ledelegálásánál. Ebben az esetben a vezetők tudják és elfogadják, hogy a beosztottak hibázhatnak is, és ezzel együtt vállalják a jogok és kötelezettségek átruházásának következményeit.

A szolidaritás elve megfogalmazza az emberek egymásrautaltságát, amely a közjó fogalmában is megjelenik. A közösségi tudat, az egymásért érzett és viselt felelősség jelenik meg ebben az alapelvben. Gyakorlati megvalósulása a társadalmi és/ vagy gazdasági értelemben kiszolgáltatott helyzetben élőkkel vállalt együttérzés, az ő tevőleges segítésük karitatív intézmények felállítása és működtetése által, érdekeik számontartása a döntéshozatalban.

\section{Az emberközpontú (keresztény) vállalkozás alapelvei - Az ember és a munka viszonya}

A Szentírás több helyen is kiemelt figyelmet szentel az ember munkához való viszonyának. Maga a Teremtés könyve is a hat napos isteni munkavégzésről szól, melyet követően a hetedik napon a Teremtő megpihen és élvezi munkája gyümölcsét ${ }^{9}$. Ezzel együtt az Isten meghívja az embert, hogy 'munkatársává' válva folytassa az általa megkezdett munkát és ebben az értékalkotó folyamatban 'tálentumai' szerint ő is vegyen részt. II János Pál pápa 1981-ben írt Laborem excercens kezdetű encikliájában megfogalmazza az emberi munka teológiai hátterét. Ebben szétválasztja a munkavégzés objektív és szubjektív jellegét a következők szerint: a munka objektív jellege az az értékteremtő, alkotó folyamat, amely eredményeként egy termék, szolgáltatás lát napvilágot. A szubjektív nézőpont azt a tevékenységet jelöli, amely által az ember megvalósíthatja önmagát, kibontakoztathatja képességeit. Az ember a szubjektív értelemben alanya a munkának, nem pedig eszköze vagy termelőereje, és mint ilyen minden esetben több és fontosabb, mint a munka objektív értéke. A két termelési tényező kapcsán a Pápa megjegyzi, hogy míg a munkaerő személyes jellegű, addig a tőke eszköz tulajdonságokkal bír, ezért a munka sohasem válhat a tőke

\footnotetext{
${ }^{9}$ „Elkészült tehát az ég és a föld, s azok minden ékessége. A hetedik napra befejezte Isten a munkáját, amelyet végzett, és a hetedik napon megnyugodott minden munkától, amelyet végzett. Megáldotta Isten és megszentelte a hetedik napot, mert azon nyugodott el minden munkájától, amelyet végezve teremtett Isten." (Ter 2, 1-3)
} 


\section{TEMATIKUS TANULMÁNYOK - Menedzsment: vezetők, vezetés és munkavállalók}

eszközévé - azaz a munka van az emberért és nem fordítva! (Az emberi méltóság elve) (II. János Pál pápa 1981)

Globalizált világunkban egyrészt tendencia, hogy próbáljuk minél kevesebb emberi munkával előállítani a szükséges anyagi javakat, ugyanakkor meg kell jegyezni, hogy a bérmunka világa napjainkban is meghatározó, hiszen a javak egy jelentős részét még mindig a fejlődő országokban (India, Kína, Délkelet-Ázsia és Afrika országaiban) állítják elő bérmunka igénybevételével.

A fő kérdés az, hogy mi a vállalkozás alapvető célja? Minek az érdekében és kinek a javára tevékenykedik? A szükségletek (igazságos) kielégítése vagy a profit hajszolása fontosabb-e? Kétségtelenül ezekre a kérdésekre többféle válasz adható, még egyazon vállalkozás esetében is. A profit realizálása szükséges, de nem elégséges feltétele a sikeres vállalkozásnak. Fontos tényező, hogy a véghezvitt tevékenységek szolgálják a köz javát is, ugyanakkor figyelembe kell venni az externáliák kezelését is. Az önmeghaladás képessége tehát ismét megjelenik, legalább vezetői szinten, amikor a menedzser ráérez arra, mi az a termék vagy szolgáltatás, amely a másik boldogságát is szolgálhatja. Ebben a szellemiségben a vállalat nyeresége három részre oszlik, (1) a vállalkozás saját részére, mely garantálja folytonos működésének feltételeit, (2) a munkavállalók hányadára, akik nélkül a profit, termék vagy szolgáltatás nem jött volna létre, és (3) részben a közösség javára. Ehhez azonban egy nagyon fontos előfeltétel beteljesülése szükséges. Nevezetesen kell, hogy legyen egy karizmatikus, emberi értékek által vezérelt (nem feltétlenül hívő) vezető, aki számos különleges vállalkozói képességet ötvöz. „Indítéka a létfenntartás mellett a kibontakozás, kreativitás, a vállalkozói szellem, a társadalmi presztízs és a vágy a közjó szolgálatára (Tóth 2017: 412)."

Ezzel összhangban az Igazságosság és Béke Pápai Tanácsa 'Az üzleti vezető hivatása'10 (2014) címü kiadványában a vállalkozások gyakorlati alapelveit a következőként foglalja össze:

1. A világ szükségleteinek kielégítése termékek és szolgáltatások biztosításával és azok folyamatos fejlesztésével

1.1. Az a vállalkozás, amely hasznos, jó termékeket állít elő, és amely olyan szolgáltatásokat kínál, amelyek ténylegesen az embert szolgálják, az a közjó elérését segíti.

1.2. Szolidaritás vállalása a szegényekkel, a szükséget szenvedőkkel. (szolidaritás elve)

2. Hatékony és értelmes munkaszervezés

2.1. A vállalkozás az emberi munka méltóságát állítja előtérbe, ezáltal is szolgálva a közösséget.

${ }^{10}$ Elgondolkodtató „Lelki tükröt” találnak az érdeklődők a kiadvány végén, ahol az üzleti vezetőket 30 figyelemfelhívó kérdésen keresztül értékelhetik saját munkájukat. 


\section{TEMATIKUS TANULMÁNYOK - Menedzsment: vezetők, vezetés és munkavállalók}

2.3. A vállalkozás lehetővé teszi, hogy alkalmazottai saját felelősségükre cselekedjenek, hozzájárulva a vállalat küldetésének megvalósításához. (szubszidiaritás elve)

3. Törekvés a fenntartható jólétre és a javak igazságos elosztására

3.1. A vállalkozás a rendelkezésére álló tőkével, emberi és környezeti erőforrásokkal ésszerűen és fenntartható módon gazdálkodik.

3.2. A vállalkozás igazságosan osztja el az erőforrásokat az összes az érintettek között (alkalmazottak, beszállítók, vásárlók, befektetők és a közösség).

\section{Következtetés, összegzés}

A keresztény társadalmi elvek közel háromszáz évvel ezelőttig befolyásolták a gazdaság szereplőit is. Ezek ez elvek a bibliai tanításokon alapultak és lényegük az volt, hogy egységes keretét adják a fóbb erényeknek. A globalizációs folyamatok erősödésével ez a keret felbomlott és helyébe a haszon és nyereségmaximalizáló szemlélet lépett, ami sokszor az emberi méltóság megsértésével éri el célját. Bár az utilitarista szemlélet alapfilozófiájában benne van a többi ember tisztelete és érdekeinek figyelembe vétele, vezérgondolata mégis a „lehető legtöbb hasznot a lehető legtöbb ember számára”. Ebből a gondolatból adódik az ellene megfogalmazható legrelevánsabb kritika apropója is, az egyéni érdek feláldozható a köz oltárán, ha a többség érdeke ezt megköveteli.

Tanulmányunkban igyekeztünk áttekinteni a különböző menedzsmentfilozófiák emberképét, és egy emberközpontúbb alternatívát felvázolni a keresztény típusú vállalatirányítás tárgyában. A magát megszólítva érző Olvasóban talán további kérdések merülnek fel a 'hogyan tovább' és a gyakorlati példák kapcsán. Meglátásunk szerint a hazai tapasztalatok és lehetőségek további vizsgálati kérdéseket rejtenek magukban.

\section{Irodalom}

Arisztotelész (1984): Politika. Gondolat Könyvkiadó, Budapest

Baranyi, Á. (2017): Keresztény társadalometika. In: Baritz, S. L. - Dabóczi, G. (szerk.): Emberközpontú gazdaság, KETEG Alapítvány

Bentham, J. (1977): A Fragment on Government. Cambridge University Press, 2001, p.xiv, https://books.google.hu/books?id=hTSwCKh2P2UC\&pg=PR14\&lpg=PR14\&dq=quotation+beccaria+la+massima+felicita+divisa+nel+maggior+numero \&source=bl\&ots=Alq0iD93u7\&sig=98ZAySsoexv0TwBYDSSNSX_ 


\section{TEMATIKUS TANULMÁNYOK - Menedzsment: vezetők, vezetés és munkavállalók}

tHU0\&hl=hu\&sa=X\&ved=0ahUKEwju3Zbhyo3WAhWPmLQKHXt0BvkQ6AEIMTAC\#v=onepage\&q\&f=false, Utolsó letöltés: 2017. augusztus 05.

Csapóné R. T. (2008): Üzleti etika. Főiskolai jegyzet, Budapesti Gazdasági Főiskola KVIFK

Easterlin, R. A. (1974): The Economics of Happiness. http://www-bcf.usc.edu/ easterl/papers/Happiness.pdf, Utolsó letöltés: 2017. július 26.

Ferenc pápa (2013): Evangelii gaudium. http://uj.katolikus.hu/konyvtar.php?h=451, Utolsó letöltés: 2017. július 25.

Fidrich, R. (2002): Nemzetek feletti vállalatok a globalizáció korában. Magyar Természetvédők Szövetsége. http://mek.oszk.hu/01400/01450/01450.htm, Utolsó letöltés: 2017. július 25.

Fromm, E. (1975): In: Tóth Gergely, Gazdasággép. L'Harmattan - KÖVET Egyesület, 2016,60 .

Green, D. (2016): The world's top 100 economies: 31 countries; 69 corporations. (2016.09.20.)https://blogs.worldbank.org/publicsphere/world-s-top-100-economies-31-countries-69-corporations, Utolsó letöltés: 2017. július 25.

Harrington, M. - Childs, M. - Briel, E. (2014): Az üzleti vezető hivatása. Gondolatok. Az Igazságosság és Béke Pápai Tanács és KÉRME Egyesület, Budapest

Heller, Á. (2004): Cinizmussal a képmutatás ellen. In: Mandeville, B.: A méhek meséje avagy magánvétek - közhaszon, Helikon Kiadó

II. János Pál pápa (1981): Laborem excercens. http://uj.katolikus.hu/konyvtar. php?h=203 Utolsó letöltés: 2017. augusztus 04.

II. János Pál pápa (1991): Centesimus Annus. http://uj.katolikus.hu/konyvtar.php?h=86\#JB20, Utolsó letöltés: 2017. augusztus 13.

Kék, E. (2017): A katolikus Egyház társadalmi tanításának rövid ismertetése. In: Baritz, S. L. - Dabóczi, G. (szerk.): Emberközpontú gazdaság. KETEG Alapítvány

Kriston, L. (2010): Megdöbbentő adatok: itt az éhínség világtérképe! http://www. piacesprofit.hu/klimablog/fenntarthato_fejlodes/megdobbento_adatok_itt_az_ ehinseg_vilagterkepe/, Utolsó letöltés: 2017. augusztus 13.

Mandeville, B. (2004): A méhek meséje avagy magánvétek - közhaszon. Helikon Kiadó

Muzslay, I. (1995): Gazdaság és erkölcs. Márton Áron Kiadó, Budapest

Schumacher, E. F. (1991): A kicsi szép. Közgazdasági és Jogi Kiadó, Budapest

Szabó, K. R. (2017): Az utilitarizmus. In: Baritz, S. L. - Dabóczi, G. (szerk.): Emberközpontú gazdaság. KETEG Alapítvány 
www. metszetek.unideb.hu

\section{TEMATIKUS TANULMÁNYOK - Menedzsment: vezetők, vezetés és munkavállalók}

Szilas, R. F. (2017): Keresztény emberkép és menedzsment. In: Baritz, S. L. - Dabóczi, G. (szerk.): Emberközpontú gazdaság. KETEG Alapítvány

Tornielli, A. - Galeazzi, G. (2015): Ferenc Pápa. Ez a gazdaság öl. Jezsuita Kiadó Budapest

Tóth, G. (2007): A valóban felelős vállalat. KÖVET Egyesület, 2007

Tóth, G. (2016): Gazdasággép. L’Harmattan - KÖVET Egyesület, 2016

Tóth, G. (2017): Ugorjuk át a keresztény közgazdaságtant! In: Baritz, S. L. - Dabóczi, G. (szerk.): Emberközpontú gazdaság. KETEG Alapítvány

Tóth, J. (2017): A közjó vizsgálata az érdekek rendszerén keresztül. In. Baritz, S. L. Dabóczi, G. (szerk.): Emberközpontú gazdaság. KETEG Alapítvány

Internetes hivatkozások:

1. A magyar nyelv értelmező szótára: „ökonómia” szócikk http://mek.oszk.hu/ adatbazis/magyar-nyelv-ertelmezo-szotara/kereses.php?kereses $=\% \mathrm{C} 3 \% \mathrm{~B}$ 6kon\%C3\%B3mia, Utolsó letöltés: 2017. július 10.

2. Wikipédia: „oikosz” szócikk: https://hu.wikipedia.org/wiki/Oikosz, Utolsó letöltés: 2017. július 10.

3. Magyar Katolikus Lexikon: „közjó” szócikk: http://lexikon.katolikus.hu/K/k\%C3 \%B6zj\%C3\%B3.html, Utolsó letöltés: 2017. július 10.

4. Wikipédia: „Arisztotelész etikája” szócikk: https://hu.wikipedia.org/wiki/Arisztotel\%C3\%A9sz_etik\%C3\%A1ja, Utolsó letöltés: 2017. július 10.

5. Wikipédia: „Aquinói Szent Tamás” szócikk: https://hu.wikipedia.org/wiki/Aquin\%C3\%B3i_Szent_Tam\%C3\%A1s, Utolsó letöltés: 2017. július 10.

6. World Happiness Report, 2017, http://worldhappiness.report/wp-content/uploads/sites/2/2017/03/HR17.pdf, Utolsó letöltés: 2017. augusztus 30.

7. Az Egyház társadalmi tanításának kompendiuma. A Közjó elve. 165. cikk, p 67. http://www.fvr.hu/new/images/stories/documents/kompendium.pdf, Utolsó letöltés: 2017. július 15.

8. Magyar Katolius Lexikon. „közjó” szócikk: http://lexikon.katolikus.hu/K/k\%C3\% B6zj\%C3\%B3.html, Utolsó letöltés: 2017. július 10. 